\title{
GLOBÁLIS HATÁSOK ÉS (ÖN)KORMÁNYZATI SZEREPEK A XXI. SZÁZAD ELEJÉN*
}

\author{
Bordás Péter ${ }^{l}$
}

Nyilvánvalóvá vált a XX. század globális gazdaságában, hogy az új jelenségek új kihivások elé állitják a kormányzást, így a helyi kormányzati egységek müködését is. ${ }^{2}$ Míg nálunk a szocializmus meghatározó eszméje terjedt, addig az 1970-es évektöl a fejlett nyugati államokban a neoklasszikus irányzat vált meghatározóvá, mely a kormányzati szektor leépitését, a magán szféra elötérbe helyezését hangsúlyozta a XX. században folyamatosan növekvö állami szerepekkel szemben. Ezt a folyamatot ún. New Public Management (NPM) mozgalomnak is szokás nevezni, mely szintén egy válságokkal teli idöszakban nyert táptalajt. ${ }^{3}$ Mindenesetre a 2007-ben kibontakozó válságig ez volt a meghatározó közgazdasági és gazdaságpolitikai gondolkodás alapja, melyet a Washingtoni Konszenzus is nagyban elösegitett. Utóbbi tartalmára vonatkozóan több közgazdász, köztük a Nobel-dijas Joseph Stiglitz és Paul Krugman is negativ birálatot fejtett ki. Mindazonáltal a rendszerváltó országok többsége, így Magyarország is, kicsit megkésve a neoliberális gazdaságpolitikával találta magát szemben, melyet az Európai Unióhoz való csatlakozási tárgyalások csak fokoztak.

A kétezres évektől már nemzetközi színtéren fokozódtak az olyan álláspontok, amelyek például a túlságosan, a piaci szereplőkre támaszkodó közfeladat-ellátást, vagy épp a piaci szereplők szabályozatlanságát állították előtérbe. ${ }^{4}$ Majd a gazdasági válság kibontakozását követően, mind a kormányzás hatásmechanizmusaiban, mind pedig a szakirodalmakban előtérbe kerültek az állam erősebb szerepét hangsúlyozó elgondolások. Ennek oka alapvetően a válság, majd az azt követő gazdasági visszaesés és az államháztartási bevételek csökkenése volt. Így tovább terjedt az a szemlélet, hogy az állami feladatok sokrétüek, rengeteg pénzbe kerülnek, s a feladat-ellátás nem hatékony. Ezt pedig több esetben azzal magyarázták, hogy a magánszereplők bevonásának eredménye a korrupció, a drágább ellátás, a felelősség és elszámoltathatóság hiánya, így újra kell gondolni az állami szerepeket. ${ }^{5}$

\footnotetext{
${ }^{*}$ DOI $10.21867 / \mathrm{KjK} / 2017.3 .4$.

${ }^{1}$ Dr. Bordás Péter, tudományos segédmunkatárs, MTA-DE Közszolgáltatási Kutatócsoport

${ }^{2}$ Lásd erről részletesebben az MTA-DE Közszolgáltatási kutatócsoport: „A kormányzás kihívásai a mai piacgazdaságba” címủ kutatásának eredményeit: www.kozjavak.hu, www.publicgoods.eu.

${ }^{3}$ A magyar terminológiában Új Közmenedzsment, melyről lásd részletesebben: Horváth M. Tamás: Közmenedzsment. Dialóg Campus, 2005, Budapest-Pécs.

${ }^{4}$ Bartha Ildikó: Kormányzási szintek és térbeli kapcsolatok. In: Horváth $M$ Tamás - Bartha Ildikó (szerk.): Közszolgáltatások megszervezése és politikái. Merre tartanak? Budapest, Dialóg Campus Kiadó, 2016. 777-792. old.

${ }^{5}$ Vigvári András: Kormányzati szerepvállalás a globalizálódó gazdaságban pénzügyi nézőpontból. In: Radványi Tamás (szerk.) Pénz és társadalom: Dolgozatok a BGF Pénzügyi és Számviteli Kara tudományos mühelyéből. Budapest: Budapesti Gazdasági Főiskola, 2011. 9. old.
} 
A közfeladatok ellátásában tapasztalható kormányzati szintek közötti átrendeződés, úgy gondolom, hogy önmagában nem jelent problémát, számos tényező előidézheti azt, melyre a kormányok nyilvánvalóan eltérő módon reagálnak. Érdemesnek tartom ezért egy kicsit részletesebben elemezni a közszektorban érvényesülő trendeket a gazdasági válságot követő időszakban.

Jó kiindulási pontot jelent a témához a COCOPS projekt, mely 10 európai uniós tagállamban - köztük Magyarországon is - vizsgálta a reformokat közmenedzsment stílusú megközelítésben 2011-2014 között. ${ }^{6}$ A tanulmány mind a negatív, mind a pozitív trendekre próbál fókuszálni, igaz alapvetően a központi költségvetési hatásokra tekintettel. Megemlíthető például, hogy Franciaország, Belgium vagy épp Magyarország esetében alapvetően a költségvetési megszorítások képezték az állami szektor változását. Addig Norvégia, Olaszország vagy épp az Egyesült Királyság esetében megjelent a hatékonyság és a teljesítmény kapcsolata is a reformfolyamatban. A vizsgálat hazánk esetében a hatékonyság bizonyos növekedését említi, melyet a közfeladatok centralizációjával magyaráz. Ezzel szemben arra is felhívja a figyelmet, hogy a reformok révén az átláthatóság nem erősödött Belgium, Magyarország és Spanyolország esetében. Nagyon érdekes a választópolgárok kormányokba vetett bizalmának kérdése. ${ }^{7}$ A felmérés alapján a 10 országban általános tendencia volt a kormányzatokba vetett bizalom csökkenése, kivéve hazánkban. Tehát ez alapján a hazai centralizációs folyamat a választópolgárokban a biztonság és bizalom érzetét keltette. A várható nemzetközi tendenciákra reagálva a szerzők számos utat jelölnek meg, köztük a Magyarországon is érezhető centralizációs folyamatot, de ilyen jelenségekről számoltak be Hollandia, Norvégia és Olaszország esetében is, igaz nem akkora méretekben, mint nálunk.

A válság hatására előkerülő problémák tehát nemcsak nemzetközi szinten hozták felszínre a kormányzati beavatkozás lehetőségét, hanem Magyarországon is. ${ }^{8}$ Hazánkban a 2010-es évektől érezhető az állami szerepek növekedésének igénye és gyakorlata, mely számos probléma együttesére vezethető vissza. Ezeket Lentner Csaba az alábbiak szerint foglalja össze:

- a neoliberális gazdaságpolitikai modell tartós válsága,

- felértékelődő állami szerepek a közhatalmi funkciók területén,

- a dekonjunktúra ciklusok ellensúlyozása a szociális-társadalompolitikai beavatkozások területén,

- Keynes gazdaságfilozófiájának reneszánsza 2007-től,

- $\quad$ sikeres fiskális és monetáris politika fordulatra, majd

- fenntartható növekedésre képes magyar állammüködés. ${ }^{9}$

\footnotetext{
${ }^{6}$ A kutatás eredményeit lásd részletesebben: Curry, Dion - Blijleven, Wieke - Van de Walle, Steven: Current and Future Trend sin Public Sector Reforms. COCOPS Work Package 8, 2014, 4-30.

${ }^{7}$ Curry, Dion - Blijleven, Wieke - Van de Walle, Steven: Current and Future Trend sin Public Sector Reforms. COCOPS Work Package 8, 2014, 5-25. old.

${ }^{8}$ Nagy Zoltán: A közpénzügyi támogatások rendszere és szabályozása. In: Lentner Csaba (szerk.): Adózási pénzügytan és államháztartási gazdálkodás - Közpénzügyek és államháztartástan II. Nemzeti Közszolgálati és Tankönyv Kiadó, Budapest, 2015, 203. old.

${ }^{9}$ Lentner Csaba: Általános államháztartási ismeretek. Közigazgatási szakvizsga diasor. NKE-VTKI, Budapest, 2015. augusztus. Elérhető: http://vtki.uni-nke.hu/uploads/media_items/3-modul-diasor2015.original.pptx (letöltés dátuma: 2017. január 27.)
} 
Mindezek eredményét úgy foglalja össze Lentner Csaba, hogy: „Így adódik, hogy hazánkban, Magyarországon is meg kell erösíteni a kormányzást, növelni kell az államháztartás hatékonyságát. Csak az erős állam képes arra, hogy garantálja az ország függetlenségét, határainak és állampolgárainak sérthetetlenségét, megóvja a polgárait a bünözéstől és a terrorizmustól."10 E célok valóban kihívás elé állították a hazai kormányzást is, de talán utalhatunk arra is, hogy e feladatok megvalósítása nem csupán az „erős állam” koncepciója révén hajtható végre. Ahogyan Gellén Márton fogalmaz, az állam a saját válságát áttelepíti a társadalomra azáltal, hogy blokkolja a közérdek megfogalmazását és érvényesítését. ${ }^{11}$ Mindazonáltal megjegyzem, a válság által felszínre hozott problémák kezelésére hivatkozással véghezvitt állami szerepek növekedése (mint például hazánkban), önmagában nem tekinthető elfogadhatatlannak, sem pedig alkalmatlan feladat-ellátási megoldásnak. A kérdés, a „mit és hogyan” feltevésen van, s annak tapasztalatai határozzák meg a választ is. A fent említett okok és indokok mellett megkezdődött hazánkban is a válságkezelésre adott reformfolyamat. Ennek egyik fontos eleme az önkormányzati rendszer és a helyi feladatok körének újragondolása volt. Az állami szerepek esetleges növekedésével ugyanakkor a vizsgálataim azt mutatják, hogy a legtöbb Európai Uniós tagállamban nem csökkent a lokális szint szerepe, sőt inkább növekedett, tehát nem az alsóbb szintü kormányzatoktól vontak el feladatokat. Ezt mutatja be a 1. számú táblázat, mely a 2006 és 2015 közötti időszakban szemlélteti az Európai Unió 28 tagállamának alsóbb szintủ kormányzati egységek kiadásainak változását a GDP \%-os arányában. Az adatok értelmezéséhez kiemelném, hogy Németország, Ausztria, Spanyolország és Belgium esetében a nemzeti szint alatti valamennyi kormányzati szint kiadását összevontan tartalmazza a táblázat, tehát így a tartományi szintekét is.

Az állami szerepek változása, nevezetesen a feladatok növekedését a költségvetések kiadási oldalának változásával tudjuk jellemezni. Jelen írás a helyi kormányzati szint és a központi kormányzat közötti hangsúly eltolódásokra próbál fókuszálni. Ennek keretén belül az európai tendencia az adatok alapján úgy írható le, hogy a legtöbb tagállamban vagy nem változott jelentős mértékben a helyi szint súlya, vagy éppen növekedett a kiadások alapján (például Belgium, Finnország, Dánia, Svédország esetében).

Öt országot tudunk megemlíteni, ahol csökkent a helyi szint költségvetési kiadása (a táblázatban halvány kékkel jelölve az országok), köztük legjelentősebb mértékben Írországban és Magyarországon. A 2006-os 12,7 \%-ról 7,8-7,9 \%-ra csökkent a helyi költségvetés a GDP arányában mérve hazánkban, tehát körülbelül harmadával csökkent. A legjelentősebb csökkenés ugyanakkor Írország esetében figyelhetö meg, ahol a korábbi, amúgy is alacsony 6,5 \%-ról 2,2 \%-ra csökkent a helyi kiadási szint. Mint tudjuk, Írország a gazdasági válság után Görögországgal együtt jelentős pénzügyi gondokkal szembesült, mely megoldást kívánt. Előbbi esetében tehát a helyi szintü pénzügyi kapacitások csökkenése is bekövetkezett.

${ }^{10}$ Lentner Csaba: Közpénzügyek és államháztartástan. Nemzeti Közszolgálati és Tankönyv Kiadó, Budapest, 2013, 49.

${ }^{11}$ Gellén Márton: Ha válság, akkor reform. Kalandozás a közigazgatási reformok forrásvidékén. In: Gellén Márton - Hosszú Hortenzia (szerk.): Államszerep válság idején. CompLex, Budapest, 2010, 207. 
Az alsóbb szintü kormányzati egységek kiadásainak változása a GDP \%-os arányában 2006 - 2015 között, az Európai Unió 28 tagállamában

\begin{tabular}{|c|c|c|c|c|c|c|c|c|c|c|}
\hline & 2006 & 2007 & 2008 & 2009 & 2010 & 2011 & 2012 & 2013 & 2014 & 2015 \\
\hline $\begin{array}{l}\text { Az EU 28 } \\
\text { tagállamának } \\
\text { átlaga }\end{array}$ & 11,1 & 11,0 & 11,3 & 12,1 & 11,9 & 11,6 & 11,6 & 11,4 & 11,3 & 11,1 \\
\hline Ausztria & 16,9 & 16,5 & 17,1 & 18,4 & 18,4 & 17,6 & 17,6 & 17,8 & 17,9 & 17,9 \\
\hline Belgium & 21,1 & 20,7 & 21,7 & 23,2 & 22,7 & 23,0 & 23,3 & 23,7 & 23,5 & 26,6 \\
\hline Bulgária & 6,4 & 6,4 & 7,1 & 8,2 & 7,2 & 6,6 & 6,6 & 7,9 & 9,0 & 10,4 \\
\hline Ciprus & 1,8 & 1,8 & 1,7 & 1,9 & 2,0 & 2,1 & 1,8 & 1,5 & 1,6 & 1,6 \\
\hline Csehország & 11,0 & 10,4 & 10,5 & 11,6 & 11,3 & 12,3 & 11,3 & 11,4 & 11,5 & 11,4 \\
\hline Dánia & 32,5 & 31,3 & 32,1 & 35,8 & 35,8 & 35,6 & 35,9 & 35,5 & 35,4 & 34,9 \\
\hline $\begin{array}{l}\text { Egyesült } \\
\text { Királyság } \\
\end{array}$ & 12,0 & 11,9 & 12,5 & 13,5 & 13,2 & 12,5 & 12,9 & 11,5 & 11,0 & 10,9 \\
\hline Észtország & 9,2 & 9,4 & 10,8 & 11,2 & 9,8 & 9,3 & 9,7 & 9,9 & 9,3 & 9,5 \\
\hline Finnország & 19,2 & 18,9 & 20,0 & 22,3 & 22,4 & 22,6 & 23,4 & 23,8 & 23,8 & 23,6 \\
\hline Franciaország & 10,8 & 11,0 & 11,2 & 11,9 & 11,5 & 11,4 & 11,7 & 11,9 & 11,8 & 11,4 \\
\hline Görögország & 3,4 & 3,4 & 3,6 & 4,1 & 3,8 & 3,1 & & 3,5 & 3,3 & 3,4 \\
\hline Hollandia & 14,3 & 14,5 & 14,8 & 16,4 & 16,2 & 15,5 & 15,1 & 14,2 & 13,9 & 14,5 \\
\hline Horvátország & 11,9 & 11,8 & 11,6 & 12,1 & 11,7 & 11,5 & 11,8 & 12,2 & 12,4 & 11,9 \\
\hline Írország & 6,4 & 6,6 & 7,0 & 6,2 & 5,4 & 4,7 & 4,3 & 3,6 & 2,9 & 2,2 \\
\hline Lengyelország & 13,6 & 13,3 & 14,0 & 14,5 & 14,9 & 13,9 & 13,2 & 13,1 & 13,3 & 12,8 \\
\hline Lettország & 9,9 & 10,3 & 11,8 & 12,6 & 12,0 & 10,8 & 10,0 & 10,2 & 10,0 & 9,3 \\
\hline Litvánia & 8,4 & 8,2 & 9,2 & 10,7 & 11,1 & 10,0 & 9,3 & 8,3 & 7,9 & 7,9 \\
\hline Luxemburg & 4,8 & 4,7 & 5,0 & 5,7 & 5,3 & 5,1 & 5,0 & 5,0 & 4,9 & 4,6 \\
\hline Magyarország & 12,7 & 11,6 & 11,3 & 12,0 & 12,6 & 11,4 & 9,3 & 7,5 & 7,8 & 7,9 \\
\hline Málta & 0,6 & 0,6 & 0,5 & 0,6 & 0,6 & 0,7 & 0,8 & 0,7 & 0,6 & 0,5 \\
\hline Németország & 19,8 & 19,3 & 19,7 & 21,3 & 21,0 & 20,7 & 20,4 & 20,8 & 20,9 & 20,8 \\
\hline Olaszország & 15,2 & 14,6 & 15,1 & 16,5 & 15,7 & 14,9 & 14,9 & 15,0 & 14,7 & 14,5 \\
\hline Portugália & 6,5 & 6,7 & 7,1 & 7,5 & 7,4 & 6,8 & 6,2 & 6,6 & 6,0 & 5,9 \\
\hline Románia & 8,6 & 9,7 & 9,7 & 9,9 & 9,5 & 10,3 & 9,6 & 9,2 & 9,0 & 9,7 \\
\hline Spanyolország & 20,7 & 21,3 & 22,5 & 24,5 & 24,5 & 24,9 & 24,3 & 21,9 & 22,0 & 21,9 \\
\hline Svédország & 23,3 & 23,2 & 23,9 & 25,2 & 24,3 & 24,5 & 25,1 & 25,3 & 25,3 & 25,0 \\
\hline Szlovákia & 6,5 & 6,1 & 6,1 & 7,3 & 7,3 & 6,8 & 6,4 & 6,4 & 6,7 & 7,5 \\
\hline Szlovénia & 8,6 & 8,3 & 9,0 & 9,8 & 9,8 & 9,4 & 9,6 & 9,8 & 9,9 & 9,0 \\
\hline
\end{tabular}

Forrás: az Eurostat adatai alapján saját szerkesztés ${ }^{12}$

Összességében azt látjuk, hogy a 2008-as év után csak minimális csökkenés volt észrevehetö, mely nem is egységes és nem folyamatszerü. Arra lehet így következtetni

12 Government revenue, expenditure and main aggregates 2006 - 2015, Elérhető: http://ec.europa.eu/eurostat/data/database (letöltés dátuma: 2017. július 31..) 
az Európai Unió 28 tagállamának éves adatait figyelembe véve, hogy a hazánkban és még egy-két országban tapasztalható ilyen mértékü folyamat nem általános jelenség, tehát a helyi szint feladatainak, kiadásainak általános csökkenése nem igazolható. Ha pedig tendenciát szeretnénk meghatározni, akkor épp ellenkezőleg, az alsóbb kormányzati szintek szerepének - bár nem kiugró - növekedése figyelhető meg.

A költségvetési adatok elemzése azt mutatja, hogy a válság hatására történt változás a kormányzati szintek közötti pénzügyi kapcsolatokban, de az nem a magyar megoldáshoz hasonló centralizációs folyamattal írható le. Számos esetben épp a helyi szint pénzügyi, újraelosztó szerepének növekedése figyelhető meg. Tehát a gazdasági válság az önkormányzati pénzügyekre is hatással volt, de a vizsgált európai országokban a problémák kezelésében nem a helyi költségvetési megszorítások játszották a fö szerepet. Söt, több esetben a helyi szint pénzügyi-újraelosztási szerepének erősödése volt megfigyelhető. Továbbá azt a következtetést is levonhatjuk, hogy nincsenek standard válaszok az egyes globális jelenségekre, így egy válság idején sem. Az egyes országok eltérő módon válaszolnak a közfeladatok szintek közötti megosztására és finanszírozására. Tehát önmagában nincs jó vagy rossz kezelési megoldás, azok eredményeinek értékelésével vonhatunk le következtetéseket.

\section{Források jegyzéke:}

- Bartha Ildikó: Kormányzási szintek és térbeli kapcsolatok. In: Horváth M Tamás - Bartha Ildikó (szerk.): Közszolgáltatások megszervezése és politikái. Merre tartanak? Budapest, Dialóg Campus Kiadó, 2016. 777-792. old.

- Curry, Dion - Blijleven, Wieke - Van de Walle, Steven: Current and Future Trend sin Public Sector Reforms. COCOPS Work Package 8, 2014, 5-25. old.

- Gellén Márton: Ha válság, akkor reform. Kalandozás a közigazgatási reformok forrásvidékén. In: Gellén Márton - Hosszú Hortenzia (szerk.): Államszerep válság idején. CompLex, Budapest, 2010, 207. old.

- Horváth M. Tamás: Közmenedzsment. Dialóg Campus, 2005, Budapest-Pécs.

- Lentner Csaba: Közpénzügyek és államháztartástan. Nemzeti Közszolgálati és Tankönyv Kiadó, Budapest, 2013, 49. old.

- Nagy Zoltán: A közpénzügyi támogatások rendszere és szabályozása. In: Lentner Csaba (szerk.): Adózási pénzügytan és államháztartási gazdálkodás Közpénzügyek és államháztartástan II. Nemzeti Közszolgálati és Tankönyv Kiadó, Budapest, 2015, 203. old.

- Vigvári András: Kormányzati szerepvállalás a globalizálódó gazdaságban pénzügyi nézőpontból. In: Radványi Tamás (szerk.) Pénz és társadalom: Dolgozatok a BGF Pénzügyi és Számviteli Kara tudományos mühelyéböl. Budapest: Budapesti Gazdasági Főiskola, 2011. 9. old.

- Lentner Csaba: Általános államháztartási ismeretek. Közigazgatási szakvizsga diasor. NKE-VTKI, Budapest, 2015. augusztus. Elérhető: http://vtki.uninke.hu/uploads/media_items/3-modul-diasor-2015.original..

- https://krugman.blogs.nytimes.com/2015/07/12/killing-the-european-project 